\title{
The City is more than just a Destination: An Insight into City Branding Practices in Croatia
}

\author{
Daniela Angelina Jelinčić \\ Institute for Development and International Relations, Zagreb, Croatia \\ e-mail:daniela@irmo.hr
}

\section{Feđa Vukić}

Faculty of Architecture, School of Design, Zagreb, Croatia e-mail:fvukic@arhitekt.hr

\section{Iva Kostě̌ić}

Faculty of Architecture, School of Design, Zagreb, Croatia e-mail: ikostesic@arhitekt.hr

\begin{abstract}
The article insists on a clear difference between place branding (city or nation branding) and destination branding, while a number of Croatian and some Southeast European cities, recognizing tourism as economic opportunity, tend to see their urban space almost exclusively as various destinations. Branding processes follow exactly the same line of development, often failing to include the main fabric of the city - the local community itself. In the article, branding processes of selected cities in Croatia and branding projects in several Southeast European cities have been researched. The results show that the majority of them have designed their brand identities as if tourism was the only cultural and economic fact the community has to offer. Places are turned into destinations and destination branding methods work only towards attracting the outsiders, which then results in the lack of sustainability for the insiders. Thus communities become 'tourism products' and, within such a framework, the issues of the real city identity, its carriers and forms are neglected. In the article the top-down approach to place branding is revisited, new factors - cultural and social participation - are recognised in the reconfiguration of economy and identity. This calls for grounding the place branding methods on the issue of self-perception connected to the vision of communal development. Thus a new concept of identity system is proposed as a theoretical frame for the working methodology. It is a new
\end{abstract}


approach to branding (or rather identity making) which enables individuals to contribute to the collective symbolic framework respecting the city and its citizens while at the same time allowing outsiders to get to know its substantial values.

Key words: place branding, destination branding, tourism, participation, Croatia.

\section{Introduction}

Process of globalisation, which characterises the times we live in, enhanced the need of cities to strive for the market as the cities now compete globally and not only regionally. In order to reach more consumers, investors, international employers, cultural and/or sports events, international fairs, students or tourists, cities find different ways to attract them. One of them is by way of branding. A number of texts have been written on branding benefits (such as Aaker, 1996; Anholt, 2009; Holt, 2004; Kavaratzis, 2008; Moor, 2007; Shocker, 1995) and a number of cities have capitalised on branding processes and outcomes (such as Amsterdam, Barcelona, Newcastle, New York, Salzburg) which brought them different benefits. They are primarily sought in economic regeneration whereas image creation/improvement follows. Although tempting for the decision-makers, focus on economic benefits promised by the branding processes, at the same time, deserved negative images in terms of selling the city for others' benefits. Throught recent decades various stakeholders tried to incorporate culture in the branding processes which was supposed to soften the harsh image economic branding was about. Thus, we witnessed the development of the creative city concept which introduced cultural, soft power branding but again with the same aim: revitalizing the economy of urban centres. The objectives may have had a more human face since the revitalisation of the economy focused on "cultural and social developments offering attractive jobs, particularly to young people" (UNCTAD and UNDP, 2008). It was again in a close connection with the market since cultural goods were commodified just as any other value used in branding process. This called for new markets whereas the growing trends in cultural tourism consumption seemed as a fertile ground. Besides, it was not always an easy task to convince decision-makers on the need to invest in culture due to its powerful impacts on urban regeneration. If, however, culture is "linked to tourism, as a strong economy, the decision-makers' confidence grows" (Jelinčić, 2011). Even if culture is not the main brand, tourism always promises new markets so cities often see this industry as the one towards which branding strategies should be directed. At the same time, tourism is a natural ally to branding and communication activities of tourism offices' and is perceived as a legitimate presentation of a city/nation to global audiences. In this process, the tourism product (holiday) is of a secondary value while this is a chance to transfer new information: what a city/state looks like, what its people do and produce, what their climate/food/culture/history is (Anholt, 2009). Although such branding strategies may bring benefits to the community, the fact that they are top-down driven often results in dissonant effects for the local community itself which eventually also brings negative effects for the tourist experiences. This is due to false representations of the community whereas the main aim of the branding strategy is to increase the number of visitors avoiding the possibility for the internal publics (the local community itself) to participate in the branding 
process. In other words, tourism branding strategies often use the projected identity instead of the existing identity (see Vukić, 2013). Analogy is found in the strategic versus organic branding: while strategic branding follows the top-down approach and is created from above, organic branding "is branding from the inside out... (It entails) creating a brand based on the ... culture itself" (Bonigala, 2010). Organic branding "develops a brand DNA based on the meaning and purpose" (Hook, 2010) of the branded product, a place in this case. This is a key difference between the place branding and destination branding. The purpose of the article is to explain this difference and to show it within the branding practices of several Croatian cities.

\section{Destination Branding vs. Place Branding}

Place branding can be defined as "the process of discovering, creating, developing and realizing ideas and concepts for reconstructing place identities, their defining traits and genius loci, and subsequently building the sense of place, by efforts and investments in hardware (e.g. infrastructure, buildings), software (e.g. events, stories), orgware (e.g. co-operative organisational structuring) and virtual ware (e.g. symbols and symbolic actions, websites)" (Govers, van 't Klooster and Van Keken, 2016). By accepting this definition of the place branding, it is necessary to acknowledge the need to communicate the real identity of a place, by way of its genius loci and the sense of place, which is in close connection with values, perceptions and attitudes of insiders (citizens). While strategic branding may easily satisfy all other (hardware, software, orgware and virtual ware) needs in creating a place brand, it is extremely difficult to communicate the sense of place while employing the topdown approach. Genius loci has to do with what the place really is, what its people are, how they live, what they do, what public spaces look like and how people use them, etc. Therefore, it comes from within or "from the inside out", as Bonigala (2010) put it. Sense of place is most easily communicated by organic branding which means that the people and places speak for themselves in the process of the brand communication.

In the global competition for markets (in terms of people, resources, investments or business) a number of places try to reach also tourism market. In order to hastily achieve such a goal, the cities often use strategic destination branding usually employed by public administrations as to create place brands "based on the visual, verbal, and behavioural expression of a place, which is embodied through the ... overall place design" (Zenker and Braun, 2010). Destination branding is actually the marketing of tourism: "applying the appropriate marketing concepts to planning a strategy to attract visitors to a destination" (Kolb, 2006). The top-down approach in this process is often static and fails to communicate the real place identity which often confuses the place branding for destination branding. Therefore, destination branding is mainly headed towards outsiders failing to include the existing city identity shared by insiders. This misunderstanding is often visible if tourist destination promotion and the real situation in the city are compared. It means that sometimes even false bigger-better-more beautiful images are communicated in order to compete in the over saturated global tourism market. On the other hand, employing 
the organic branding adds to the dynamism and allows real place identities to be revealed.

One can argue that any type of branding is about turning a city into a product. Thus, it is often thought that city branding purpose is turning a city from a place into a destination. Branding can bring a number of benefits to a city "including reducing consumer purchase risk, building awareness by communicating a consistent message, encouraging repeat visits by building consumer loyalty, and associating the city with a unique identity" (Kolb, 2006). While there is nothing wrong with branding a city, there are flaws in the process of turning a place into a destination since it entails that the branding process is directed towards outsiders who are customers of the city and to whom the city serves as a short-term destination. It can be legitimate when a city goal is to increase the number of visitors; still, a city must not be turned into a destination since it excludes the real reason for its existence: the city is a city because of its citizens and its principal customers are its citizens. Good branding can make cities desirable; it is necessary, though, that they are first desirable to their own citizens and then to outsiders such as tourists.

The main goal of the destination branding is to "communicate the benefits received from a visit" (Kolb, 2006) which adds to the visitors' experience. Although there are differences between good and bad destination branding, the fact remains that in practice, destination branding is often directed only towards tourists while neglecting its internal publics. It often results in bland and cosmetic branding programmes focusing almost entirely on external audiences and employing superficial advertising techniques, presenting interchangeable clichés about lovely food and welcoming citizens (Morgan and Pritchard, 2011). This makes it a paradox situation since if communication about community values is not accepted by the community itself, how can it be really verified towards its external target groups (Vukić, 2013)?

It is, therefore questionable if the traditional approach to destination branding may be employed in place/community branding. "A successful ... brand encourages cohesion internally and brings huge economic and political advantages externally" (Morgan and Pritchard, 2011). But internal cohesion is rarely involved in the process of destination branding which sees urban actors mostly as passive elements of overall image for external public rather than active stakeholders within the process.

On the other hand, most of the place branding methods have evolved out of the destination branding philosophy, where the key issue is outer image of the city and the external public is the main target in research (Hanna and Rowley, 2008:67-69). Following that model, city branding activities as destination branding are developing in four principal areas: as communication tools, perceptual units, enhancement of the values and as relations (Morgan, Pritchard, 2002:61). All four areas operate within the field of symbolic construction of identity, but focus completely on external perception of the city. The question here is to what extent is this exteriorisation of city "symbolic economy" functional for perpetual re-interpretation and re-creation of identity as a key factor of sustainable community (Zukin, 1995:1-47)? 
The usual methods of place branding projects include a complex process of a different type than destination branding which involves the whole array of stakeholders. Typical destination branding project usually derives from existing elements linked to public perception of a city seen as a destination only. Created elements are often used as value enhancers serving to an image communicated to outsiders. While the existing elements are usually associated with organic branding (the identity of the community as found, what a community really is), created elements are related to strategic branding (what city officials want to communicate). The first one is the bottom-up, and the second one top-down approach. Top-down branding approaches usually consider only a few elements of a city identity which in the long term can hardly be effective (Vukić, 2013). Identity is a dynamic variable and changes over time which may have huge impacts on community branding. This is why strategic branding is often considered as temporary if not even erroneous branding method. On the other hand, organic branding is seen as a branding with a human face respecting local identity values. In the same way, destination branding usually brings pejorative connotations while place branding, if not totally deprived of a negative image since it still turns a city into a product, seems softer and more inclusive. The other problem which occures is the project implementation and its development over time, which in typical destination branding presumes tourist promotion in printed and digital media only. There is little, if any, involvement of city actors, the citizens, in the afterlife of the project throughout the dynamic of life.

Mommaas has noted that city brands which reflect only cleaned-up "cappuccino and croissant" image of middle class urbanity will not be in accord with the real-life conditions of the majority of citizens. In the worst-case scenario, he sees an active opposition of citizens to the newly created communication symbols and strategies, ultimately producing completely unexpected consequences (2002:43). Regarding high level of identity expressions, despite very structured vernacular identity policies and practices, described as "revolutions of identity as a historic turn in a way of social construction of individual" (Kaufmann 2006:98), there is a certain need to reinvent the traditional city branding practice and replace it with more suitable identity system to meet the needs of real urban life actors, and not only for the purpose of image building.

Both modern and postmodern city are the role model for organizing various types of communal life, tourist destination included. So, the basic function and the power of the concept of identity is at play no matter what sort of activity prevails within the economy. Interdisciplinary approach to the issue of identity sees it as a variable, a fluid category changing along the cultural, economy and political lines of activity within the community (Abdelai et al., 2006). The identity is structurally seen as a multiple dimension of urban life in two layers: as a content and a contestation. The content describes the meaning of collective identity in four forms: constitutive norms defining belonging to the community, social purposes shared by the community, relational ideas on other identities and communities and, finally, cognitive models of understanding material and spiritual reality. Contestation relates to the level of agreement on content shared within the community. 
This concept is present in today's cities and can be characterised as organic (but not deliberate) branding process, and is especially seen in the appearance of sharing economy products ${ }^{1}$ which resulted in the increased number of citizens becoming tourism stakeholders while "tourism is penetrating further into the fabric of the city" (Richards, 2016). Participative practices have become usual not only on the supply side but also on the demand side which is visible in a number of creative tourism programmes satisfying the tourists' needs to participate in authentic experiences. The emergence of existential authenticity as a marker of tourism has led to a growing appreciation of the local as an important bearer of authenticity. Since many consumers already know that tourism offers a series of staged experiences, they are increasingly looking for local and daily life as something that is not represented (Richards, 2016). The WYSE Travel Confederation research confirms that 85 percent of travellers younger than 35 years of age think that experimenting with the local is one of the main motives for travel (2013). This may also affect branding strategies possibly making them more organic, participative and bottom-up driven.

Still, what happens when organic tourism products start to look alike? Although citizens becoming Uber drivers or Airbnb hosts may not have had the initial intention to be part of the tourism industry, they see it as an added (or, for some of them, main) economic value. They are locals, insiders, and the fact that they interact with tourists is a perfect foundation both to satisfy tourists needs for the local and daily as well as to add to the organic branding of the community. Paradox is that a number of Airbnb lodgings start to look alike. Seen as an excellent way for personal income increase, Airbnb lodgings rarely reflect the real local spirit but are intentionally furnished with IKEA products which allow for designed items for less money. Although such lodgings are indubitably cosy and suit tourists needs, the question remains if they really reflect the local. Greg Richards' research has shown that Airbnb hosts in Barcelona are among the most educated and most traveled people who have the cultural capital to understand and cater to the needs of tourists. And they understand that what tourists want from their local Airbnb experience is actually an IKEA version of the local: clean, bright, white and designed. In fact, as witnessed by the crowds that fill the two IKEA stores in Barcelona, this may also be what many locals want (Richards, 2016).

This, actually reveals that what is often considered authentic and local (such as local cultural heritage for example) and what is usually taken as the brand identity in the usual branding processes, may have nothing to do with what community considers as local. The case of Barcelona in Richards' research shows that the citizens know that IKEA is neither local nor authentic for a certain location either than the Swedish ones, but it represents how local community lives today and thus reveals the local daily life. It reveals what the community really is and what its relation to tourists is.

1 Such as Airbnb, Uber, Turo or Lyft. Also, services such as Booking.com and TripAdvisor have provided both outbound and inbound markets with high level of information on destinations which raises awareness of stakeholders within destinations to actively participate in the branding processes. 
Then again, if a place brand entails distinguished features of a certain location which makes it different from the other ones, then the question is if we are really talking about branding in this case. Although it is definitely organic, it does not mean that it is branding at all; we might rather see it as non-deliberate (branding) processes which reflect the citizens' democratic decisions to participate in the city tourism activities. This, eventually also has impacts on place identity.

On the other hand, another research which reflected tourism marketing practices for the Caribbean islands revealed that the unique selling propositions (USP) which used to be the underlying concept of the most marketing processes are abandoned. Rather, they are replaced by the new concept of attraction diversity index representing "a measure of the diversity of attraction types in a destination area" (Henthorne, George and Miller, 2016). Such an index was created since the research outcomes confirmed that it was the diversity of attractions in a destination that were far more important for branding than their actual number. The research, therefore confirms that branding changed its concept: the focus is on the diversity of attractions and not on USPs.

The following chapters focus on the branding strategies/projects in the selected cities of Croatia and Southeast Europe which provides empirical grounds for the proposal of a new theoretical concept.

\section{Approaches to Branding Practices in Croatian Cities}

The branding projects in several cities in Croatia have been evaluated in order to detect the methodology used in the city branding as to define whether the process focused on the city as a place or as a destination only. The research conducted by the authors in November-December 2016 focused on several cities in Croatia which were selected with regard to their size, their importance in tourism, and their geographical position. Aside from desk research, a questionnaire on city branding was sent by e-mail to both city representatives and tourist boards ( 14 addresses in total) in order to identify which methodology was used (if any) in the process of branding. The questionnaire consisted of eight questions regarding city branding research: 1) who commissioned the research?; 2) who carried it out?; 3) when was the research carried out?; 4) how long did the research take?; 5) what research methods were used?; 6) who were respondents?; 7) what was the number of the respondents?; 8) what was the aim of the research? The questionnaire was sent to city management offices and tourist boards of seven cities - Zagreb, Karlovac, Pula, Zadar, Šibenik, Split and Dubrovnik - and the responses were sent from only five of them (Zagreb, Karlovac, Pula, Zadar, Šibenik, all of which were sent by the cities' tourist boards). The replies to the questionnaires were incomplete providing only partial factual data. In order to reconstruct and identify the branding methods used by the cities noted above, due to the lack of detailed information sent from the respondents, the research was in large part grounded on relevant public documents available on the web. 
The importance of (re)branding of Zagreb was clearly noted in "ZagrebPlan 2020", a document covering the strategic plan of the city development. The document was brought by the City Office for the Strategic Planning and Development of the City, and one of the measures was "identification, advancement and development of a unique approach to identity communication of Zagreb", the result of which would be a "clear and applicable communication system that would affirm local identity in the context of globalisation/integration processes" (Gradski ured za strategijsko planiranje i razvoj Grada Zagreba, 2012). No further project was carried out as a result, but this may have been the reason for a brand research sent out by the City of Zagreb in 2014. Out of 3005 respondents, 1500 were citizens of Zagreb, 1000 citizens of Croatia and 505 tourists that visited Zagreb (Kovačević, 2015). The results of this research were formally never represented to the public.

The Zagreb City Tourist Board commissioned a research carried out by a consulting agency (specialized in tourism and leisure) in 2011 with the aim of making a strategy for tourism branding of Zagreb and a marketing plan for foreign market, through identifying the opinion about Zagreb among the citizens of top five European markets, as well as those from Croatia. The research was carried out through interviews (37 among four foreign markets and Zagreb) and questionnaires (924 travellers from Europe and Croatia, not including Zagreb) (Horwath HTL, 2011). The results were published, but no branding project resulted as the outcome of the research.

In 2009, the City of Karlovac commissioned a PR agency to convey the research on the identity and image of Karlovac for the purposes of "city branding". The twelve month research included the opinions of citizens of Karlovac and Croatia (Grad Karlovac, 2010). The result was a new city logo and a slogan, whereas no evidence of participation by the citizens in carrying out any of these activities was documented.

The new tourist brand of the city of Pula was commissioned by the City Tourist Board through the public competition for a new visual identity. The research and branding begun in 2008 and were carried out by a design and branding agency. As with the case of Karlovac, city branding was accomplished only at the level of the city's logo that is used both with the city management office and the tourist board, creating visual consistency of the city's visual identity. It was made as part of the destination branding project with which the brand agency won the „2010 Rebrand 100 Global Award” (Društvo arhitekata Zagreba [DAZ], 2012). Unfortunately, the details of the research are unknown to the general public.

As for Zadar, the importance of branding is noted in key documents regarding the tourism sector. It is proposed that Zadar should be branded, among other things, as a city of puppetry. The research was carried out among local citizens (1324), tourists (1499) and stakeholders (Turistička zajednica Grada Zadra, 2016). It is not clear though, in what research they ground their branding choice (aside from a long tradition of puppetry in Zadar). In the "Development Strategy of Zadar 2013 - 2020" branding is related to the "ultimate purpose of attracting tourists", and it represents "highlighting the identity or some elements of identity for commercial purposes" (ZADRA, 2013). Still, it is recognized that the motive for branding is not necessarily 
aimed at tourism development. But further on, city branding is only mentioned in the measure of tourism development (ZADRA, 2013).

The Šibenik City Management commissioned a research carried out by a Croatian brand consultant from 2010 until 2013, on 4000 respondents of all ages, educational levels and statuses, both from internal and external public. The research results point out that the city brand must be in coherence with the opinion of both the internal (citizens of Šibenik) and external public (Jakovljević, 2012). The aim of the research was to "find the minimum of approval that would bring stakeholders to dismiss their own interests in favour of the interests of the community". No further project development concerning branding was carried out as a result (Vukić, 2016b).

Regarding Split and its city branding, neither City Management Office nor the Tourist Board sent their responses. The Dubrovnik City Tourist Board never conducted such a research (Vukić, 2016a).

The research results on the branding processes in five analysed cities, are presented in Table 1.

Table 1

Comparative results analysis of branding process methods used by the cities of Zagreb, Karlovac, Pula, Zadar and Šibenik

\begin{tabular}{|l|c|c|c|c|c|}
\hline & Zagreb & Karlovac & Pula & Zadar & Šibenik \\
\hline Methodological approach & top-down & top-down & top-down & top-down & top-down \\
\hline Aim & tourism & $\mathrm{N} / \mathrm{A}^{*}$ & tourism & tourism & $\begin{array}{c}\text { tourism/ } \\
\text { community }\end{array}$ \\
\hline External public & + & + & - & + & + \\
\hline Internal public & + & + & - & + & + \\
\hline Results & - & $\log /$ slogan & $\log /$ slogan & - & - \\
\hline
\end{tabular}

"Data not provided by the respondent; still, it could be concluded that the research was aimed at least at tourism development since the response has been received by the Tourist Board.

Source: authors

The research results show that all the researched cities employed top-down approach in their idea of what a city branding should be. Therefore, strategic and not organic branding was a theoretical concept for these activities. All the cities, with the exception of Pula included both external and internal public in the research, and the research for the mentioned cities was mostly tourism aimed. Therefore, the awareness of the need for research of both internal and external public existed. 
Although this could represent grounds for further actions, no further branding process has been carried out in Zagreb, Zadar and Šibenik so it is not possible to draw conclusions on the projects' success. In the case of Karlovac and Pula, the only visible outcome of the branding process are the new city logos and slogans with no evidence of citizens' participation.

The results point to the efforts which aim to create symbolic programs to promote the cities and are conducted within the local entities basing their economies mostly on tourism, hence are perceived as destinations only, as places to come and exist for a short period of time. Most of these activities are carried out by local tourist boards and with none or minimal research preparations, and are by all means focused on the creation of key visual sign and slogan meant to promote competitive advantages of the destination to external public, i.e. potential guests.

\section{An Insight into Branding Projects in Southeast Europe}

The problem of getting the whole and complex structure of city life down to one dimension - an image of tourist destination, and a standard practice of city authorities and tourist boards not to involve citizens in the active creation of symbolic structure for communication is not just a problem in Croatia, but also in Southeast Europe, where tourist activity is of a large scale. The authors performed a desk research of web sources and digital media focusing on city and tourist boards web pages the selected cities which include tourism as a significant economic driver ${ }^{2}$. The research was performed over the same period as the research on branding projects in Croatia. The results of the research of Southeast European cities, however, present only outcomes of the desk research without further knowledge on branding processes as in the case of analysed Croatian cities which makes these two researches only partially comparable. The research of branding projects in Southeast Europe, therefore, is rather seen as an insight into the branding outcomes which require further research but the results are indicative of lack of branding practices in general; they showed that mostly traditional heraldry is used to identify the city. In few cases (mostly tourist resorts, such as Ohrid, Brasov, Neum and Mikonos for example), there were examples solely based on creation of visual and verbal elements to communicate to external public without any evidence that these communication elements are the result of any research conducted upon external and/or internal public.

Contrary to the risen awareness that city branding is not just for external activities and "not just for the tourists" (European Cities Marketing, 2016), the city authorities are still struggling to do a research and to get consulting agencies solely for the purpose to communicate with the potential guests and investors. Such research studies are established on the rather usual misinterpretation of bringing the complex

2 Sofia, Plovdiv, Varna and Burgas in Bulgaria; Bucharest, Brasov, Constanta and Timisoara in Romania; Skopje and Ohrid in Macedonia; Athens, Santorini, Mikonos and Thessaloniki in Greece; Zlatibor, Niš, Beograd and Novi Sad in Serbia; Sarajevo, Mostar, Banja Luka, Neum and Međugorje in Bosnia and Herzegovina; Kiev in Ukraine. 
issue of identity down to an image, which should prove to be efficient in relation to external public, but needs not to have any bond with the values that citizens hold as important (seenews.com, 2013). Research activities of this kind mostly analyse the media image of the cities, which is a normal result of citizens' activities and identities, but the results are of a doubtful value for the establishment of an effective identity system in which, presumably, the citizens would take an active role to share the individual values with the collective. Few examples (Kiev and Budapest ${ }^{3}$ ) which have undertaken such branding activities prove that this one-dimensional approach to city identity is still prevailing. For example, Kiev had acquired a new logo and slogan through the public competition and the only input that participants got were the images (The Branding Source, 2012) with no evident facts that any research was conducted on citizens' opinion on the city identity. The city of Budapest has recently initiated the creation of a new logo and a slogan as a foundation for a brand system and the underlying concept is that "residents need to genuinely identify with it" (We Love Budapest, 2016). For the outcome of this process a city authority agency was established.

Another project which is of a larger scale and should be mentioned here is the European Capital of Culture (ECoC) project as one of the incentives of the Europen Union offering cities of (Southeast) Europe a possibility to develop and create a city brand. Some of the cities, such as Sibiu (2007, Romania), Pécs (2010, Hungary), Maribor (2012, Slovenia), and Košice (2013, Slovakia) (European Commission, 2017) have established communication systems to serve this need but there is no evidence that these new symbolic values continued to develop for the sake of betterment of the lives of their citizens. It will be interesting to follow the preparation process of Rijeka 2020 ECoC, as this project might involve insiders (citizens) in participatory building of the new, rediscovered city identity. As the candidacy process already employed participatory public engagement, it might prove as a good platform for future initiatives.

Both in Croatia and Southeast Europe "city branding" is mostly practised as "destination branding" and in most cases with top-down method, seen in theory as a "new strategic tool for urban management" (Anttiroiko, 2014:61-69, 153-163) with little or no involvement of citizens, either in research or development procedures for the establishment of complex symbolic systems for the city. In Western Europe though, it is clear for at least a decade now, and pointed out in theory and consulting literature, that destination does not comprise all of the city structural and social complexity (Kavaratzis, 2008), so some projects carried out, (such as Copenhagen or Amsterdam), demonstrate an inclination towards a more complex approach to creation of city brands (Moilanen and Rainisto, 2009:77-94). However, in terms of methodology there is still no wider, more established proof of the branding practice, that city actors - citizens - should be included both in research and implementation

3 Although Budapest, as a Central European city was not originally selected for this research, it was included in it since it shares similar historical environment as Southeast European cities. It may also serve as a comparative reference point. 
of city branding activities. Therefore, across the Western world and not only within Southeast Europe, city branding is still a philosophy evolved from the product and corporate branding, seen as a management tool for city authorities. The key question that might be raised is if this method is sustainable and if branding is an appropriate method at all or should be upgraded to a level which should suit better the neeed of a community.

\section{Conclusion and a Further Scenario: From City Brands to Identity Systems}

The research has shown that most branding processes of the selected cities in Croatia and Southeast Europe (if they are performed) practice strategic branding whose main outcome is superficial advertising serving mostly tourism purposes. This entails top-down approach in branding strategies which is primarily directed towards external public. City authorities rarely participate in research activities connected to the city identity and citizens are rarely consulted on the purpose and meaning of the newly created communication systems and its development in project implementation phases. There arises a paradox of the lack of participation within the symbolic level of city existence: citizens are extremely involved in tourist activities but rarely given a chance to participate in the creation of symbolic programs of communication. This is mostly evident in Croatia, where national economy significantly depends on tourism. It is difficult to force individual(s) to idenitfy with the idea of a community (the city) as projected from some outer actor(s)-consultant(s). Also, an evident problem lies in the physical infrastructure of the tourist cities, where everyday life and public spaces are submitted to and manipulated by tourist activities to a large extent thus interfering with daily life needs and routines and causing the problems to community (Vukić et al., 2015:485-487).

Relevant contemporary literature stands for a more complex approach to city branding processes which implies the city as place, and not just a destination, which is confirmed by several good practice examples. Still, not even Western Europe confirms to have created a participative branding process for citizens to be included on all levels, from the idea of the project to its implementation and development.

Interdisciplinary approach to the issue of identity proposed by Abdelai et al. (2006), in contemporary cities also encounters the idea of "entrepreneurship city" (Kavaratzis, 2008:31) which includes far more complex policies and practices of identity, planned and projected as most of the entrepreneurial activities. Therefore, the free enterprise city identity is forming in a complex interplay of self-perception and external image, within the context of mass communication, mostly of commercial type. The city as an entrepreneur is a usual stance taken by the authorities in starting the branding programs. But there is another possibility to theorize and practice city branding, the one which drives social process of identification between individual(s) and the idea of community. This is precisely where the concept of identity system could enter as a substitute to traditional city branding. The key resource here is the idea of "cultural knowledge" as a sum of overall identity potential, the baseline of found identity as a solid ground for the designed identity (Holt, 2004:209-210). As 
noted, there is a built-in paradox within the theory and practice of city branding, which constantly diminishes the potential of self-regulatory and self-manageable identity practices by the citizens.

A new approach to the city identity should take into the research and design perspective at least three issues. First, the issue of "cultural citizenship" i.e. the new level of identity construction in which - due to global communication network - the individual does not need to be connected with the other one in physical space to participate in same values (Delgado-Moreira, 1997). Second, the issue of "shared identity" which is not just a mechanical division of individual and collective identity but a more complex type of construct spreading through various levels of technological ambient of today (Phelps et al. 2002:211-224). Third, the issue of identity crisis, the heterogeneity, multi-ethnicity and multicultural aspects of life in the cities of the traditional West, started long before the migration crisis of today, which process constructs in new and unexpected ways in the collective identities of the citizens' life (Gospodini, 2002:19-36).

Based on this, therefore, rather than offering a closed conclusion, a new conceptual approach to the city identity is proposed, the one which should replace traditional top-down method and complement it or even replace it with the bottom-up and multidirectional interaction among urban stakeholders (Vukić, 2013) in the changing dynamics of identity construction. The concept is regarded as the "identity system" and could upgrade the concept of city branding practised as a management tool to a level of democracy apparatus to serve the symbolic needs of citizens. The proposed concept is all embracing in terms of including insiders and outsiders, internal and external public in the branding processes which may eventually solve the problem of the extent of exteriorisation of city "symbolic economy" posed by Zukin (1995).

It is presumed that the proposed identity system concept could prove as flexible enough to meet the ever changing dynamism of negotiation between global and local cultural exchange. The tourists' need for diversity of attractions and local need for globalised products stressed at the beginning of the article could potentially be reconciled through a constant and fluid facilitation by this concept.

Even within the theory and practice of product brands, there are serious debates on complex social networks of meaning, described with the concepts such as "consumer democracy" or "citizen brandship" (Gobe 2002: XV, 229). It is not possible to avoid the discussion on the creation of symbolic system for such a network as the city. The productive identity system would not only promote the consumption of the city experience but should foster the identity sharing within the community, too. Without this inclusive dimension, no city brand will be sustainable.

The proposed system is still, however, a philosophical issue proposing the replacement of the city branding concept with the concept of the democratic apparatus, and its practical implementation could be extremely demanding. The prerequisite to its implementation is the citizens' will for participatory decision-making about the symbolic representations of the city they live in, which, further on presumes cer- 
tain knowledge. Such a knowledge also includes a sum of overall identity potential or "cultural knowledge" concept proposed by Holt (2004) which would rather be process- and not goal-oriented, this meaning the creation of the city identity system rather than its brand. It also presumes a high level of tolerance and openness towards the "others" with whom the identity is shared within the city, as well as the sense of belonging to the city. The implementation identity system concept also requires a participative approach which may include workshops, public discussions and creation of flexible communication systems which may, thanks to digital technology, enable active and permanent citizen participation. Through such communication systems, citizens would be given an opportunity to easily express their idea on the community thus contributing to its the constant re-interpretation. Outcomes of the process may result in a reflective deconstruction of the city identity but with the aim of creating a shared space by the citizens themselves, therefore the insiders, thus providing sustainable grounds for the city identity communication to the external public, the outsiders.

For sure, communication is relevant for any type of individual or communal activity, but if the idea of the city is still regarded as a tourist attractor, even for the individual enterprises within it, then perhaps a new level of sharing integration should be provided for the actors to build a new type of mutual trust and a symbolic engine for urban cohesion. If the concept of branding is still needed at all then, perhaps, it should enter into the new stage of conceptual development.

\section{References}

1. Aaker, D. (1996). Building strong brands. New York: The Free Press.

2. Abdelai, R.; Herrera, M. Y.; Johnston, I. A.; McDermott, R. (2006.). Identity as a variable. Perspectives on Politics, 4 (4): 695-711.

3. Anholt, S. (2009). Konkurentan identitet. Novo upravljanje markama država, gradova i regija. Zagreb: M PLUS d.o.o.

4. Anttiroiko, Ari-Veikko (2014). The political economy of city branding. Abingdon, Oxon: Routledge.

5. Bonigala, M. (2010). Organic branding: a small business success story. Retrieved 28 November 2016. (http://www.bonigala.com/organic-branding-a-small-business-success-story).

6. Delgado-Moreira, J. M. (1997). Cultural citizenship and the creation of European identity. Electronic Journal of Sociology. Retrieved 10 January 2017. (https:// www.sociology.org/content/vol002.003/delgado.html).

7. Društvo arhitekata Zagreba (2012.). Parabureau i brendiranje Pule među 26 najboljih u svijetu. Retrieved 17 November 2016. (http://www.d-a-z.hr/hr/vijesti/ parabureau-i-brendiranje-pule-medu-26-najboljih-u-svijetu,1672.html).

8. European Cities Marketing. Retrieved 10 January 2017. (http://www.europeancitiesmarketing.com/city-branding-is-not-just-for-tourists/).

9. European Commission (2017). European Capitals of Culture. Retrieved 12 January 2017. (https://ec.europa.eu/programmes/creative-europe/actions/capitalsculture_en). 
10. Gobe, M. (2002). Citizen brand, ten commandments for transforming brand culture in a consumer society. New York: Allworth Press.

11. Gospodini, A. (2002). European Cities and Place-identity. Discussion Paper Series, 8 (2): 19-36.

12. Govers, R., van 't Klooster, E. and Van Keken, G. (2016). The place brand observer. Retrieved 28.11.2016. (http://placebrandobserver.com/place-brandingprinciples/).

13. Grad Karlovac (2010). Karlovac postaje brand. Retrieved 13 November 2016. (http://www.karlovac.hr/novosti/karlovac-postaje-brand/560).

14. Gradski ured za strategijsko planiranje i razvoj Grada Zagreba (2012.). ZagrebPlan 2020 - Razvojna strategija grada Zagreba, Ciljevi i prioriteti razvoja do 2020. Zagreb: Gradski ured za strategijsko planiranje i razvoj Grada Zagreba.

15. Hanna S. and Rowley J. (2008). An analysis of terminology use in place branding. Place Branding and Public Diplomacy, 4 (1): 61-75

16. Henthorne, T. L.; George, B. P. i Miller, M. M. (2016). Jedinstvene prodajne propozicije i destinacisjko brendiranje: longitudinalna perspektiva karipskog turizma u tranziciji. Turizam, 64 (3): 261-275.

17. Holt, D. B. (2004). How brands become icons: the principles of cultural branding. Boston, MA: Harvard Business School.

18. Hook, U. (2010). Static branding vs. organic branding. Retrieved 28 November 2016. (https://www.mediavillage.com/article/static-branding-vs-organic-branding-uwe-hook-mediabizbloggers/).

19. Horwath HTL (2011). Strategija turističkog brendiranja grada Zagreba s planom promocije na međunarodnom tržištu. Retrieved 19 November 2016. (http:// www.infozagreb.hr/documents/b2b/TZGZ-Branding-FINAL-291211.pdf).

20. Jakovljević, R. (2012.). Priprema za brendiranje grada Šibenika. Retrieved 14 December 2016. (https://www.google.hr/url?sa=t\&rct=j\&q=\&esrc=s\&source=web\& $\mathrm{cd}=2 \& \mathrm{cad}=$ rja\&uact $=8 \& v e d=0$ ahUKEwi4jZD-tr7RAhWhKMAKHQWMBjMQFgge MAE\&url=http $\% 3 \mathrm{~A} \% 2 \mathrm{~F} \% 2 \mathrm{Fwww}$. sibenik.hr\%2Fpreuzmi $\% 2 \mathrm{~F} 446 \% 2 \mathrm{Fpriprema} \% 2$ 520za\%2520brendiranje $\% 2520$ grada $\% 2520 \% 25$ C5\%25A1ibenika.pdf\&usg=AFQjC NEeN587VETWGNa4hx48fvUEVvklrA\&sig2=XhUJ2ElsjjBXns6jSVONXA\&bvm=b v.144224172,d.bGs).

21. Jelinčić, D. A. (2011). Kultura kao lijek za propalu industriju, u: Černelič Krošelj, A.; Jelavić, Ž. i Rožman H. (Ur.). Kulturna dediščina industrijskih panog/Industrijska kulturna baština. 11. Vzporednice med slovensko in hrvaško etnologijo/11. Hrvatsko-slovenske etnološke paralele. Ljubljana: Slovensko etnološko društvo.

22. Kaufmann, J. C. (2006). Iznalaženje sebe, Jedna teorija identiteta. Zagreb: Antibarbarus.

23. Kavaratzis, M. (2008). From city marketing to city branding. Groeningen: Rijksuniversiteit.

24. Kolb, B. M. (2006). Tourism marketing for cities and towns. Using branding and events to attract tourists. Burlington, MA / Oxford: Elsevier.

25. Kovačević, L. (2015). A što vas asocira na Zagreb, koji su najbolji simboli grada? Večernji list. Retrieved 16 November 2016. (http://www.vecernji.hr/zg-vijesti/asto-vas-asocira-na-zagreb-koji-su-simboli-grada-994196).

26. Moilanen T. and Rainisto S. (2009). How to brand nations, cities and destinations: a planning book for place branding. London: Palgrave Macmillan. 
27. Mommaas, H. (2002). City branding. The necessity of socio-cultural goals, in: Vermeulen Marco (Ed.). City branding. Image building \& building images. Rotterdam: Nai Uitgever.

28. Moor, L. (2007). The rise of brands. Oxford, New York: Berg Publishers.

29. Morgan, N. and Pritchard, A. (2002). Meeting the destination branding challenge, in: Morgan, N.; Pritchard A. and Pride, R. (Eds.). Destination branding, creating the unique destination proposition, Oxford: Elsevier, Butterworth Heinemann.

30. Morgan, N.; Pritchard, A. and Pride, R. (2011). Destination brands: managing place reputation. Oxford / Burlington, MA: Elsevier.

31. Phelps, N. A.; McNeill, D. N. and Parsons, N. (2002). In search of a European edge urban identity: trans-European networking among edge urban municipalities. European Urban and Regional Studies, 9 (3).

32. Richards, G. (2016). El turismo y la ciudad: hacia nuevos modelos?, in: Onghena Yolanda (Ed.). Escenarios turísticos: movilidad, derechos y destinos. Revista CIDOB d'afers internacionals. 113: 71-87.

33. seenews.com. Retrieved 22 December 2016. (http://top100.seenews.com/2013/10/city-branding-mapping-the-media-images-of-the-see-capitals).

34. Shocker, A. D. (1995). Positive and negative effects of brand extension and cobranding. Advances in Consumer Research, 22: 432-434.

35. The branding source. Retrieved 20 December 2016. (brandingsource.blogspot. hr/2012/03/new-logo-kiev.html).

36. Turistička zajednica Grada Zadra (2016). Strategija razvoja turizma Grada Zadra za razdoblje 2016.-2026. Retrieved 14 November 2016. (http://onama.zadar. travel/strategija_razvoja_turizma_grada_zadra_za_razdoblje_2016_2026_godine. pdf).

37. UNCTAD and UNDP (2008). Creative economy report. Geneva, New York.

38. Vukić, F. (2013). Grad kao identitetski sustav: prema metodi sustavnog projektiranja identiteta zajednice. Zagreb: Sveučilište u Zagrebu, Arhitektonski fakultet, Studij dizajna.

39. Vukić, F.; Jukić, T.; Podnar, I.; Šarinić, J. (2016). The strategy for a living historical city: sustainable tourism as a creative collaborative practice, in: Wibowo Arif S.; Widiastuti Indah and Soemardi Ahmad R. (Eds.). Imagining experiences: creative tourism and the making of place. Proceedings Arte-polis 6 / Bandung, Indonesia: School of Architecture, Planning and Policy Development Institut Teknologi, 484-494.

40. Vukić, F. (2016a). Re: molba za podatke. Message to: Jelka Tepšić. 12 December 2016. E-mail.

41. Vukić, F. (2016b). Re: molba za podatke. Message to: Daria Lešić. 14 December 2016. E-mail.

42. We love Budapest. Retrieved 12 January 2017. (welovebudapest.com/budapest. and.hungary/budapest.becomes.the.city.that.unites.with.a.new.logo.and.style).

43. WYSE (2013). New Horizons III. A global study of the youth and student traveller. Amsterdam: WYSE.

44. ZADRA (2012). Strategija razvoja grada Zadra 2013 - 2020. Okvir za strateški razvoj Zadra do 2020. godine. Retrieved 13 December 2016. (http://www.zadra. hr/stratesko-planiranje/strategija-razvoja-grada-zadra/). 
45. Zenker, S. and Braun, E. (2010). Branding a city - conceptual approach for place branding and place brand management. Paper presented at the $39^{\text {th }}$ European Marketing Academy Conference, $1^{\text {st }}-4^{\text {th }}$ June 2010, Copenhagen.

46. Zukin Sh. (1995). Cultures of cities. Malden, MA / Oxford: Wiley-Blackwell. 
Daniela Angelina Jelinčić

Institut za razvoj i međunarodne odnose, Zagreb, Hrvatska

e-mail:daniela@irmo.hr

Feđa Vukić

Arhitektonski fakultet, Studij dizajna, Zagreb, Hrvatska

e-mail:fvukic@arhitekt.hr

Iva Kostě̌ić

Arhitektonski fakultet, Studij dizajna, Zagreb, Hrvatska

e-mail: ikostesic@arhitekt.hr

\section{Grad je više od destinacije: procesi brendiranja grada u Hrvatskoj}

\section{Sažetak}

Članak inzistira na jasnom razlikovanju brendiranja grada i brendiranja destinacije, dok hrvatski i neki gradovi Jugoistočne Europe, prepoznavši turizam kao gospodarsku priliku, vide vlastiti urbani prostor gotovo isključivo kao destinaciju. Procesi brendiranja slijede istu razvojnu liniju, često propuštajući uključiti vlastite građane kao osnovu koja čini grad. Članak istražuje procese brendiranja odabranih gradova u Hrvatskoj te projekte brendiranja nekoliko gradova Jugoistočne Europe, koji su pokazali da većina svoje identitetske brendove dizajnira kao da je turizam jedina kulturna i gospodarska realnost koju zajednica može ponuditi. Mjesta se pretvaraju u destinacije, a metode brendiranja destinacije u obzir uzimaju gotovo isključivo privlačenje outsidera (gostiju), što rezultira manjkom održivosti za insidere (lokalno stanovništvo). Tako zajednice postaju „turistički proizvodi“, a pitanja stvarnog identiteta grada, njegovi nositelji i oblici u takvom su okruženju zanemareni. Članak također revidira pristupe odozgo prema dolje u brendiranju gradova te prepoznaje nove čimbenike u rekonfiguraciji gospodarstva i identiteta: kulturnu i društvenu participaciju. To je osnova za kreiranje metoda urbanog brendiranja koje se temelje na pitanjima samopercepcije i vizije razvoja zajednice. Predlaže se novi koncept identitetskog sustava kao teorijski okvir za radnu metodologiju, što je osnovica za novi pristup brendiranju (odnosno stvaranju identiteta) koji pojedincima omogućuje da doprinesu kolektivnom simboličkom okviru. Takav sustav štiti grad i građane a ujedno omogućuje gostima da upoznaju njegove istinske vrijednosti.

Ključne riječi: brendiranje grada, brendiranje destinacije, turizam, participacija, Hrvatska. 